\title{
WORKING ON HOLIDAY: THE THEORY AND PRACTICE OF WORKCATION
}

\author{
Brigitta Pecsek ${ }^{1}$
}

Received: March 1, 2018 / Revised: May 3, 2018 / Accepted: June 27, 2018

(C) Association of Economists and Managers of the Balkans, 2018

\begin{abstract}
Work, leisure and sleep are the three core cyclical activities in our society. In the past work was distinct from non-work time, in fact 'the 8-hour work, 8-hour leisure, 8-hour sleep day' was at the very heart of past worker movements. So, the blur between work and leisure is a postmodern trend which has impacted the way we travel. This change is mainly due to the advances of technology, which have made work outside the workplace a reality even during holiday. Consequently, a hybrid tourism product called workcation has emerged and challenges the traditional concept of tourism. Both the theory and the practice of this phenomenon are in the focus of this research.

Due to the lack of the tourism-focused theorization, the related literature is multidisciplinary and eclectic; therefore, this study takes a similar approach while embedding the topic into the tourism theory. The starting point is the change in work and leisure relationship, followed by the impact of technological advances on the work. Then I also formulate a tourism-focused workcation concept. For the empirical research an online survey was conducted with 340 participants. Based on the multidisciplinary literature and the result of my empirical research six types of workcation tourists were identified and described. Finally, a specific segment of workcation tourists is singled out as an attractive market for strategists and marketers planning sustainable tourism.
\end{abstract}

Keywords: workcation, niche tourism, digital nomad, holiday stress

\section{JEL Classification Z32}

This paper was presented at the Second International Scientific Conference on Economics and Management - EMAN 2018, March 22 2018, Ljubljana, Slovenia, www.eman-conference.org

\footnotetext{
Brigitta Pecsek

bpecsek@kodolanyi.hu

1 Kodolányi János University of Applied Sciences, 1139. Budapest, Frangepán utca 50-56, Hungary
} 


\section{INTRODUCTION}

This study aims to enhance formative and comprehensive approaches to conceptualizing and contextualizing workcation tourism. In the process, it formulates a tourism-focused definition and categorises workcation tourists. Studies dealing with the imbalance of work and leisure and their negative consequences are abound (Nippert-Eng, 1996; Haar et. al., 2014; Beigi, Shirmohammadi, 2017; Maragatham, Amudha, 2016; Wee Chan, Pervaiz, 2015; Shruti et. al., 2014; James, 2014; Süss, Sayah, 2013; Messersmith, 2007; Fleetwood, 2007; Hyman et. al., 2005). However, literature on the work on holiday with a tourism-focus is hard to come by and the existing scholarly works approach the topic from the working life perspective, the concept of workcation has not been in the forefront of scholarly debate. The shortage of relevant research is partly due to the lack of theoretical framework, even the expression 'workcation' is found only in slang dictionaries (online slang dictionary 2017) defined as: "a paid work trip that can be combined with aspects of taking a vacation. From 'work' + 'vacation'". The definition is primarily related to the digital nomad, who prioritises work over leisure, so it is oversimplified and one-sided, failing to grasp the different types of workcation tourists as my study will illustrate it later.

Without a widely accepted concept, the available literature is multidisciplinary and eclectic, therefore, this research takes the same perspective, looking into time, work and leisure through wider lenses, and only after the theoretical foundation is established, workcation tourism will be embedded into the realm of contemporary tourism theory. The springboard is the relationship between work and leisure and its changes over history, which leads to the discussion of the impact of the latest technological revolution on work and leisure. This theoretical base enables me to theorise workcation tourism and the characteristics of the different workcation tourists. The empirical part of the study discusses the findings of an online survey conducted with the participation of 340 respondents regarding their working habits and stress level during holiday. The conclusions will serve a lesson for tourism marketers and strategists, if they intend to build a workcation destination.

\section{LITERATURE}

\section{Changes in working hours and leisure time}

The proportion of work time and leisure time has profoundly changed in the history of mankind and the pendulum swung back and forth. It might come as a surprise that at the turn of the 18th century weavers in France worked only 180 days a year, while Hungarians worked 255 days in 2016 (Central Statistical Office 2016). In the past even protests for more working hours took place in several parts of Europe. The turning point was the industrial revolution when automation led to the substantial increase in working hours, days and shifts.

The emblematic place where the 8-hour day was first introduced is New Lanark Mills, in Scotland, today one of the UNESCO World Heritage Sites in the country. The footsteps of the mill owner, Robert Owen was then followed by the management of Ford Motors in 1914, which resulted in double profits and improved efficiency (McGregor, 2016).

Most countries introduced the 8-hour working day in the first half of the 20th century (table 1). It is beyond the scope of this study to make a detailed theoretical analysis on a country basis, however, it is clear that the reduction of working hours could not only be related to economic performance, but other political, historical and cultural factors might have had an influence. In Russia for example it became a law during Trotsky way before the more developed Belgium, while 
Australia with British roots was the last one even lagging behind the militarily defeated and morally devastated Japan.

Table 1: The year of implementation of the 8-hour working day

\begin{tabular}{|l|l|}
\hline Country & Year \\
\hline Uruguay & 1915 \\
\hline USA & 1917 \\
\hline Russia & 1917 \\
\hline Germany & 1918 \\
\hline Spain & 1919 \\
\hline Portugal & 1919 \\
\hline France & 1919 \\
\hline Iran & 1923 \\
\hline Belgium & 1924 \\
\hline Japan & 1947 \\
\hline Australia & 1951 \\
\hline
\end{tabular}

Source: ILO, 2017

Nowadays alternative working arrangements such as shortened working weeks, flexitime, home office, job-share or temping have been gaining ground both globally and locally, and the fixed, 8hour days is slowly becoming irrelevant. It has to be noted that the reason behind the spread of these alternative working hours might not have been the demand for better work-life balance, but it was mainly initiated by the industry side first, with the aim of improving efficiency by harmonising the workload with the working time. There are sectors like the IT where professionals might have a stronger say in their work schedule, but many employees do not benefit much from the more flexible arrangements. The most extreme form of this postmodern flexitime system is the zero-hour contract, which means that companies can employ staff without ever guaranteeing work. In Britain 910000 people work on zero-hour contract (The Guardian 2017).

The long-anticipated 'Age of Leisure' (Honoré, 2005) is slipping away. A recent survey conducted by the Gallup Institute on the US workforce (2014) revealed that the total working hours of fulltime workers reached 47 on average, which is almost a whole day more than a 40-hour week they fought for a century earlier. Half of the employees clock overtime and $25 \%$ of the Americans rack up 50 hours a week. The findings also showed that people in the USA work substantially more than workers in Western Europe (Saad, 2016).

When examining work-life balance, the length of paid leave plays a key role. Looking at the length of total paid leave (paid vacation days and paid public holidays) in different European countries, workers in Austria and Malta enjoy the most work-free days, totaling 38, Hungary with 33 days is on the top third of the list (Active absence 2017). Globally, Kuwait is the frontrunner with 43 days and an extra 21-day entitlement for those who have not been to Mecca yet (Global banking finance 2017). In the United States, the average number of paid vacation days offered by private employers is 10 days after 1 year of service, 14 days after 5 years, 17 days after 10 years, and 20 days after 20 years (Bureau of Labor Statistics 2017).

\section{The role of modern technology in work-life balance}

Present-day technologies have fundamentally changed our attitude towards work and leisure. In the 1990s the spread of the Internet, later the Internet-based technical advances including smart phones or video-chats, not to mention the social media, all have revolutionized the way we communicate both in our professional and private life. Before the Internet, our communications 
depended solely on the efficiency of the postal service, which today is pushed aside due to the realtime communication forms (Gleick, 2003). Since both our official and private communications take place in the same virtual space, it poses a constant challenge to separate work from social life and it is up to the individuals and their working environment to what extent they are able to do that.

When it comes to our official dealings, e-mail has remained the main form of written communication, since all the exchanges are embedded in one another, so the whole conversation is well-documented, which makes search simple and easy. From the employer's side the main advantage of e-mail over the social media is that the whole content stays within the 'walls of the company', so from a confidentiality point of view it is less problematic to handle (HVG 2017). The same can be said for our private e-mail exchanges as well.

Compared with e-mails, the growing role of the social media in business and private life is much more controversial and conflicting. In case of tourism its role in marketing is the easiest to investigate (Albastroiu, Felea 2014; Munar, 2011). Within the social media the role of Instagram in tourism was closely scrutinized in several recent works including Bergström and Backman (2013) Fatani and Suyadnya (2015), Hanan and Putit (2014) and Murton (2014). The importance of Instagram is due to the fact that the visual manifestation reinforces the authenticity of a given attraction or destination. That is the reason why travelers are encouraged to take, post and share their own photos because potential tourists find the visual accounts of their fellow tourists more authentic than professional travel imagery.

\section{The impacts of working on holiday: tourism perspective}

As the fusion of working and private life intensifies, the fine line between work and holiday has also been disappearing. In the past the only people who worked during holiday were people on a business trip. There were limited opportunities to mix work with pleasure, if business travellers wished to pursue leisure activities, they had to extend their business trip and finance it from their own budget.

Nowadays working on holiday has become a norm, and those are the exceptions who could totally switch off and rest 24/7 without any contact with their business partners or colleagues. The collapsing borders in modern life is the focus of the oeuvre of Baumann (2000), whose theory on fluidity can also be applied to understanding postmodern tourism. According to his line of argument, the constant changes in our contemporary society makes individuals lose their identity to such an extent that they end up without roots. This is consistent with Eco's (2017) take on postindustrial society who blames the sickness of society on fluidity.

The phenomenon of fluidity is manifested in two hybrid tourism products: staycation (tourism without leaving their own environment) and workcation (working on holiday). Staycation emerged during the 2008 global financial crisis, when people were not willing to give up holiday altogether, therefore, they started to explore their own surroundings and engaged in tourism activities in the vicinity of their homes. From the perspective of tourism theory, it challenges the very definition of tourism because it raises the question: Is it necessary to move away from home to gain tourism experiences or is it enough to switch your brain into 'tourist mode'?

Workcation poses a challenge from another angle, namely, is it necessary to ignore work completely while on holiday? Based on my literature review and empirical research I formulate the following definition of workcation: 
Workcation is a hybrid type of tourism when tourists travel for either leisure or dual (business and leisure) motive and due to the modern technology, they perform both work and leisure activities away from home.

The novelty of the definition lies in the fact that it is a more inclusive approach, covering pure leisure tourists who do not have any initial working motivation, but their life circumstances compel them to work. Then it also includes tourists with dual purposes who happily mix work with leisure. The various categories are described later in the discussion part of the empirical research.

Several scholars delved into the negative impacts of work during holiday over the last decade and many of them (Deci, Ryan, 2008; Marshall, 2012; Neulinger, 1982) emphasized that the inability of switching off is a source of stress and a cause for certain illnesses because without recharging their batteries employees are not able to pick up work and perform efficiently. Gilbert and Abdullah (2004) also agree that holiday relieves stress and improves well-being.

From the employees' side the most commonly mentioned argument against workcation is the inefficiency of multitasking as Silverman (2015) cites in his work. The author underlines that the combination of work and holiday might cause that the individual cannot perform $100 \%$ in any situation. He adds that the rest deficiency might be as harmful as skipping a holiday altogether.

The survey conducted by Ascentis (2017) came to similar conclusions and identified a group of employees who are dissatisfied due to the work expectations during holiday. $40 \%$ of those holidaymakers who are forced to work on holiday actively look for a new job, in contrast, only $21 \%$ of people who have supportive working environment intend to leave their current job. It can be concluded that respecting workers' right for a rest improves loyalty. This research also revealed that people working in supportive environment feel better recognised and valued.

On the other hand, long-term negative impacts cannot be substantiated yet, and other findings came up with different conclusions. It can happen that a workcation is more beneficial for the body and mind than skipping holiday altogether (Nawijn, Damen, 2014), The researchers asked 374 Dutch people about their travelling habits and $97 \%$ were satisfied with their work-leisure balance during their vacation. The respondents pointed out that even a workcation is less stressful than coming back to a huge pile of work after holiday. Top managers and small business owners stated that working during holiday help they keep the business going without a hitch.

Academics echoed the same sentiment in a survey done by ResearchGate (2017), in which all the respondents admitted to working on holiday because they can do more research during holiday. The comments revealed that scholars enjoy workcation because after the academic year full of teaching commitments coupled with administrative duties, they can finally slow down and spend time reading scholarly literature and writing studies. For many of them the slow process of reading and writing compared with the fast schedule of the academic year is relaxing and rejuvenating.

A recent US study explored the issue of workcation from a novel angle and examined the phenomenon of work martyrs. Those employees do not take any time off, for fear that no one can fill in for them. The research completed by GFK (Gesellschaft für Konsumforschung 2017) concluded that those employees perform at a lower level than their peers, and they are rewarded less in terms of a bonus or a raise.

The main point of all the literature reviewed is that the attitude to workcation greatly depends on the individuals' job, working arrangements and the supportive or unsupportive management. The full-time employees see workcation in a more negative light, mainly because they feel that they do 
not have any time (neither working time, nor leisure time) that they can control. Small business owners and top managers have more freedom in terms of work-life balance and similarly to academics their attitude to workcation is more positive than that of the former group. The question remains: if full-time employees had the freedom to decide on work-life balance during their holiday, would that change their attitude to workcation?

\section{METHODOLOGY}

My research was completed in October 2017 when 340 Hungarian individuals, 230 men and 110 women, participated in the online questionnaire. The 12-question survey covered the frequency of holiday, the technical devices taken and used on holiday, the nature and the amount of work on holiday, and the stress associated to workcation. The composition of the sample is detailed below (table 2).

Table 2: Demographic profile of respondents

\begin{tabular}{|l|c|c|}
\hline Age & Number & \% \\
\hline Born before 1946 & 21 & $6 \%$ \\
\hline Baby boomer & 59 & $17 \%$ \\
\hline Generation X & 152 & $45 \%$ \\
\hline Generation Y Generation Z & 88 & $26 \%$ \\
\hline \multicolumn{2}{|c|}{20} & $6 \%$ \\
\hline Occupation & 340 & $100 \%$ \\
\hline Employee & 109 & $32 \%$ \\
\hline Manager/Team leader & 62 & $18 \%$ \\
\hline Executive & 63 & $19 \%$ \\
\hline Pensioner & 61 & $18 \%$ \\
\hline Student & 22 & $6 \%$ \\
\hline Self-employed & 23 & $7 \%$ \\
\hline N= & 340 & $100 \%$ \\
\hline
\end{tabular}

Source: own research

Looking at the age, generation $\mathrm{X}$ and $\mathrm{Y}$ were the two biggest groups with $71 \%$. Occupational categories were selected in a way to be understood by the Hungarian respondents and to have relevance to the actual research. In terms of occupation the proportion of students and selfemployed was negligible. The low number of the last group is unfortunate because according to the Central Statistical Office the number of small business owners with less than 10 employees reached 1.3 million in 2015. As it was established before, they have the freedom to decide on their own work-life balance, so exploring their attitude in the Hungarian context and compare it with global data would have been an eye-opening experience. However, their low level of participation in the study makes it impossible to single them out and analyse them as a separate group. The available empirical studies on workcation do not say much on the generational differences. One of the above cited research findings (Ascentis 2017) mirrors my results, they also found generation $X$ and $\mathrm{Y}$ the most active during their vacation. $82 \%$ of generation $\mathrm{X}$ argued that they feel less guilty during holiday if they can work, while $77 \%$ of generation $\mathrm{Y}$ opined in the same way. 


\section{RESULTS AND DISCUSSIONS}

The first question enquired about the frequency of taking vacations among the respondents.

Table 3: The number of vacations per year

\begin{tabular}{|l|c|}
\hline Number of trips/year & $\%$ \\
\hline less than one & 3 \\
\hline one & 41 \\
\hline $2-3$ & 47 \\
\hline more than 3 & 9 \\
\hline
\end{tabular}

Source: own research

The table 3 shows that around half of the respondents make 2 or 3 trips a year, presumably, beside their long summer vacation they also go on 1 or 2 shorter holidays. Over $40 \%$ go on vacation once a year and only $3 \%$ do not travel yearly. So, taking a holiday is a preferred leisure activity regardless of age and occupation. The national data unveils similar results, Hungarians made 18 080243 trips in 2015, which means that an individual had 1.8 trips a year (KSH 2017). Another survey commissioned by Danubius Hotels (2017) asked 6500 Hungarians and found that 53\% of them travel more than once a year.

\section{Work-related activities and technology used}

The next question was raised regarding the three most common devices that tourists take for a trip.

Table 4: Technological devices taken to vacation

\begin{tabular}{|c|c|c|c|}
\hline Frequency & \multicolumn{3}{|c|}{ Devices } \\
\hline & mobile & tablet & laptop \\
\hline always & $91 \%$ & $6 \%$ & $15 \%$ \\
\hline rarely & $9 \%$ & $29 \%$ & $41 \%$ \\
\hline never & $0 \%$ & $65 \%$ & $44 \%$ \\
\hline
\end{tabular}

Source: own research

As table 4 illustrates, mobile phones took over the role of computers on holiday, which mainly due to two main reasons. First, the wide range of functions smart phones have makes tablets and laptops unnecessary on short-term. Second, the baggage policy of low-cost airlines force passengers to travel as light as possible. Looking at the actual activities done on vacation (Figure 1), the most common activities mentioned can easily be done on the phone. Two passive activities: reading of e-mails and SMS finished on top, both can be done in parallel with leisure pursuits. The only activity that requires full attention is videoconferencing, however, only $10 \%$ engaged in this type of activity. 
Figure 1: Activities on holiday

\section{Number of mentions}

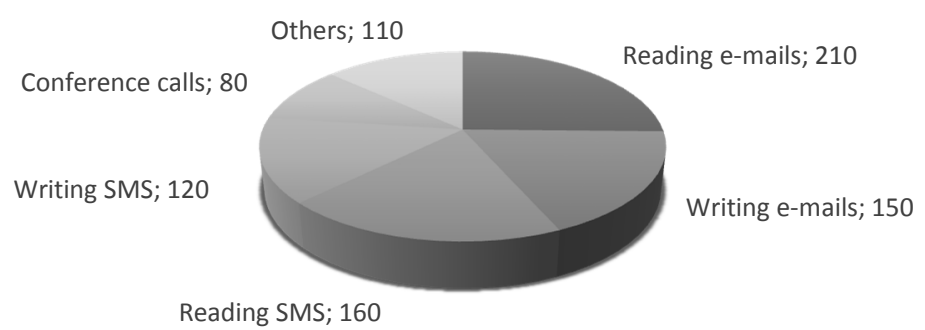

Source: own research

The HR buzzword 'multitasking' has been a fertile ground to make working activities on holiday more acceptable. Job advertisements regularly contain the ability of multitasking among their core requirements. The scope of this study does not allow to get into details, but I would cite two recent studies that proved: multitasking is unnatural and lowers the quality of work. Bradberry (2017) in his studies carried out at Stanford University found that multitasking harms the brain and decreases the IQ. Mckeown (2014) in „Essentialism” claims that 'less is more', and it is more fruitful to concentrate on one task at a time and do it right than performing several tasks simultaneously and committing errors.

The GFK (Gesellschaft für Konsumforschung 2017) asked American full-time workers who were entitled to paid vacation in its research. Out of 7331 respondents 2598 had access to work outside the workplace, therefore, only their answers were analyzed. The survey revealed that $46 \%$ of vacationists work regularly on holiday, $27 \%$ occasionally, and another $27 \%$ do not work at all. It is important to note that the $62 \%$ of regular workers do not even take the whole of their paid leave annually, so they have much less time to regenerate.

\section{Typology of workcation tourists}

The core question of this research was related to job stress on holiday (figure 2 and 3). Respondents were asked about their stress level during vacation, whether they fret about their job or the quality and speed of the Internet access. Based on the findings I could identify four main categories of workcation tourists complemented with two subcategories. It should be noted that this research has a tourism-focus and the medical perspective was completely ignored.

Figure 2: Job stress on holiday

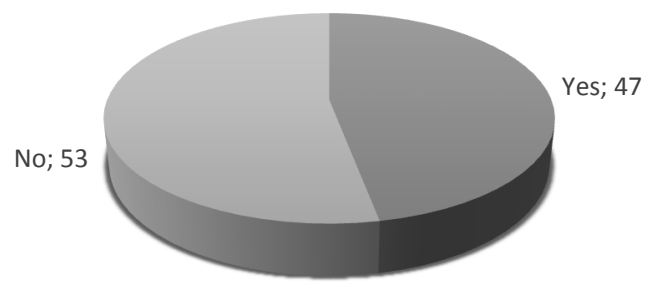

Source: own research 
Figure 3: Stress because of technology access

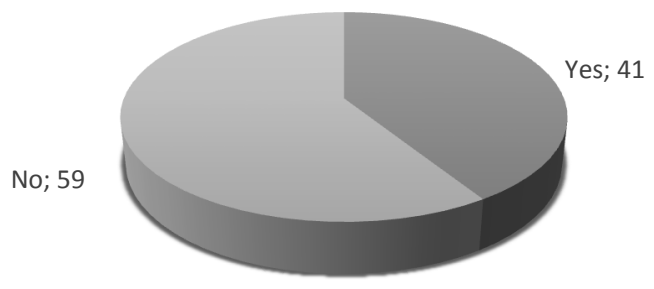

Source: own research

The two questions produced similar results, $47 \%$ said work on holiday triggers stress and $41 \%$ said that even the inaccessibility to cutting-edge technology creates stress for them. In order to find out about the extent of overlap between the two groups, I made a correlation table and found four distinctive groups, adding two subgroups identified through my background readings.

\section{Stress-sensitive workcation tourists}

About $20 \%$ of the respondents can be qualified as highly sensitive to holiday stress, all of them are generation $\mathrm{X}$ and $\mathrm{Y}$ workers, occupation wise even spread.

These vacationists agonise over work as well as the slow technology, even if they do not have to perform any tasks during their holiday. Members of this group cannot let their hair down and return to work so exhausted, as if they had not gone on holiday at all. In terms of tourism this group is the hardest to satisfy because their anxiety is independent of the holiday infrastructure and environment. In this case employers and employees together should decide on 'off duty days' that can be extended later over a weekend or a whole week.

\section{Technology - addict workcation tourists}

About $20 \%$ of the respondents are addicted to technology, slightly younger group, the whole generation $\mathrm{Z}$ and all the students are part of this group.

About $20 \%$ of the respondents are addicted to technology, slightly younger group, the whole generation $\mathrm{Z}$ and all the students are part of this group.

This group is overanxious about the quality and speed of the technology available at a given destination. They obsessively check their phones and stay connected 24/7 regardless of having work to do or not. This group is easy to please, and they do not need a wealth of cultural and entertainment opportunities. As long as their need for cutting edge technology is met, these tourists are satisfied.

\section{Workaholic workcation tourists}

About $28 \%$ of the respondents can be put into this category, overwhelmingly generation $\mathrm{Y}$, occupationwise even spread.

In psychology, this is a well-documented and researched group since workaholics existed way before the latest technological revolution. However, they did not travel extensively in the past 
because they had to stop working while travelling. In tourism it is a relatively new travel segment, which requires quality accommodation, aesthetical environment and impeccable service to keep up appearances of being a genuine holidaymaker. They take all the latest technology with them; therefore, the quality of the technical infrastructure is irrelevant.

\section{STRESS-FREE WORKCATION TOURISTS}

About $32 \%$ belong to this stressless group, mostly men (80\%), occupationwise even spread, slightly more generation $\mathrm{X}$ and baby boomers than younger generation.

These tourists can switch into 'vacation mode' and do not worry about unexpected work or inefficient technology. They can balance work and leisure in a way to keep their stress level at bay. They are ideal workcation tourists, because the sudden change in their work/leisure pattern do not influence their travel satisfaction.

a. Modern luddites: a small proportion of stress-free workcation tourists identified through the literature review, defined by Penn and Zalesne (2007) in their book „Microtrends". According to the authors there are creative professions such as writers or artists who have not succumbed to the present-day technology. For them using a typewriter, a pen or a notebook is part of the creative process, which fosters new thoughts and ideas. They are similar to workaholics in a way that inspiring and aesthetic environment is important for them. The ideal workcation retreat for them would be the contemporary version of art colonies.

b. Digital nomad: also part of the group of stress-free workcation tourists who travel for dual purposes, therefore, in a narrow sense of the word they are not qualified as leisure tourists. While compiling the main characteristics of the digital nomad (table 4) I used web pages such as becomenomad.com and online interviews and reports (Russell, 2013; Nova, 2017).

Table 4: Characteristics of the digital nomad

\begin{tabular}{|l|l|}
\hline Categories & Characteristics \\
\hline Length of stay & longer length of stay \\
\hline Preferred environment & urban or close to city \\
\hline Working environment & anywhere \\
\hline Daily routine & adapting to distant clients \\
\hline Social interaction & $\begin{array}{l}\text { they socialize with locals and fellow } \\
\text { workcation tourists }\end{array}$ \\
\hline Tourist type & slow tourist \\
\hline Need for infrastructure & the depend on modern technology \\
\hline Ecological footprint & smaller than traditional tourists' footprints \\
\hline Type of accommodation & more modest, environmentally-friendly \\
\hline $\begin{array}{l}\text { Consumer basket } \\
\text { Type of experience }\end{array}$ & $\begin{array}{l}\text { similar to locals } \\
\text { authentic experiences }\end{array}$ \\
\hline
\end{tabular}

Source: own research

This is only a selective inventory of characteristics of the digital nomad, comprising the most distinct features. These types of tourists tend to stay longer at the destination, therefore, they are considered slow tourists. Their daily routines differ from more traditional tourists because they have to adapt to their clientele who might live in different time zones. Due to their longer stay they socialize more with locals, might pick up some of their habits and customs. Digital nomads need state-of-the-art technology for their work, therefore, they prefer either city locations or to stay close 
to the urban environment surrounded by spectacular landscape, where more cultural and entertainment opportunities are available. Since their lifestyle is similar to that of the locals in many ways, their ecological footprints are smaller. Yet, it greatly depends on the modern creature comforts they use, such as car that can easily counterbalance the positive impact of the longer length of stay. By the same token, if they do not consume local food, their need for import products (transport cost, environmental damage, traffic, noise) will make their footprints even bigger than that of mass tourists.

\section{CONCLUSIONS AND RECOMMENDATIONS}

The blurring line between work and leisure is a well-documented trend in our postmodern society, which led to the emergence of workcation tourism. This research set out to explore the topic from both theoretical and practical perspectives. The author attempts to theorise workcation by formulating a workcation definition and categorising workcation tourists.

Based on the literature review and the survey findings people suffering from job stress on holiday can be divided into six categories. The results of the research unveiled some segments that can be considered and attracted when a destination plans to embark on sustainable tourism developments. Both modern luddities and digital nomads can be an ideal target market for destinations planning to build workcation retreats and complementary infrastructure as a way of economic regeneration. Some good practices in Europe are available to explore, including specific German examples that could be applied in the Hungarian context as well. Workcation will always be a niche tourism product and Hungarian developers have to keep it in mind that the majority of future guests will come from foreign countries, therefore, cultural differences and language problems should be handled with tact and professionalism.

\section{REFERENCES}

Active absence. http://www.activabsence.co.uk/

Albastroiu, I., Felea, M. (2014). The Implications of User-Generated Content Websites for Tourism Marketing. International Journal of Economic Practices and Theories, 4(2), 222229.

Ascentis. https://www.ascentis.co.uk/

Baumann, Z. (2000). Liquid Modernity and Beyond. Cambridge: Polity.

Become Nomad. www.becomenomad.org

Beigi, M., Shirmohammadi, M. (2017). Qualitative Research on Work-Family in the Management Field: A Review. Applied Psychology, 66(3), 382-433.

Bergström, T., Backman, L. (2013). Marketing and PR In Social Media: How the Utilization of Instagram Builds and Maintains Customer Relationships. Masters. Stockholm University.

Bradberry, T. (2017). Why Smart People do not Multitask. http://www.cnbc.com/2017/01/12/whysmart-people-dont-multitask.html Accessed on: 3 January 2017.

Bureau of Labor Statistics. https://www.bls.gov/

Danubius hotels. https://www.danubiushotels.com

Deci, E. L., Ryan, R. M. (2008). Facilitating optimal motivation and psychological well-being across life's domains. Canadian Psychology, 49, 14-23.

Eco, U. (2017). Chronicles of a Liquid Society. - faith, hope and clarity. Houghton Mifflin Harcourt.

Fatani, M. N., Suyadnya, I. W. (2015). Beyond User Gaze: How Instagram Creates Tourism Destination Brand? Procedia - Social and Behavioral Sciences, 211, 1089 - 1095.

Fleetwood, S. (2007). Why work-life balance now? The International Journal of Human Resource Management, (18) 3. 
Gesellschaft für Konsumforschung. http://www.gfk.com/de/

Gilbert, D., Abdullah, J. (2004). Holiday taking and the sense of well-being. Annals of Tourism Research, 31(1), 103-121.

Gleick, J. (2003). Gyorsabban. Budapest: Göncöl kiadó.

Global Banking and Finance review. https://www.globalbankingandfinance.com/

Haar, J. M. et al. (2014). Outcomes of work-life balance on job satisfaction, life satisfaction and mental health: A study across seven cultures. Journal of Vocational Behavior, (85) 3, 361373.

Hanan, H., Putit, N. (2014). Express marketing of tourism destination using Instagram in social media networking. In Sumarjan, N. et al. (Eds.): Hospitality and Tourism: Synergizing creativity and innovation in research Croydon, Great Britain. Taylor \& Francis Group. pp. 471-474.

Heti világgazdaság. www. hvg.hu

Honoré, C. (2005). In Praise of Slowness. New York: HarperCollins.

Hyman, J. et. al. (2005). Life Balance in the 21 st Century. Basingstoke: Palgrave Macmillan.

James, A. (2014). Work-life 'balance' and gendered (im)mobilities of knowledge and learning in high-tech regional economies. Journal of Economic Geography, 14(3), 483-510.

Központi Statisztikai Hivatal. www.ksh.hu

Maragatham, B., Amudha, R. (2016). Work-life balance of women bank employees in Kumbakonam Municipal Precinct. Indian Journal of Science and Technology, 9(27).

Marshall, J. (2012). Legal opinion: Working while on holiday. http://www.personneltoday.com/hr/legal-opinion-working-while-on-holiday/ Accessed on: 20 November 2017.

McGregor, S. (2016). Happy May Day from Robert Owen. http://www.thelabcn.com/blog/2016/5/2/happy-may-day-from-robert-owen Accessed on: 20. November 2017.

Messersmith, J. (2007). Managing work-life conflict among information technology workers. Human Resource Management, 46(3). 429-451.

Munar, A. M. (2011). Tourist-created content: rethinking destination branding, International Journal of Culture, Tourism and Hospitality Research, 5(3), 291-305.

Murton, D. (2014). Instagram and tourism: a perfect marketing match. http://blog.marginmedia.com.au/Our-Blog/bid/102337/Instagram-and-tourism-a-perfectmarketing-match Accessed on: 24 November 2016.

Nawijn, J., Damen, Y. (2014). Work during vacation: Not so bad after all. Tourism Analysis, 19(6), 759-767. Accessed on: 1 September 2017.

Nippert- Eng. C. (1996). Home and Work: Negotiating Boundaries through Everyday Life. 1St Edition. University of Chicago Press.

Nova, A. (2017). These digital nomads have ditched the 9-to-5 life. https://www.cnbc.com/2017/10/17/these-digital-nomads-have-ditched-the-9-to-5-life.html

Accessed on: 3 November 2017.

Nyaralási szokások felmérés. (2016): https://www.danubiushotels.com/hu/magazin/kutatas. Accessed on: 3 February 2018.

Online Dictionary. http://onlineslangdictionary.com/meaning-definition-of/workation.

Penn, M. J., Zalesne, E. K. (2007). Microtrends: The Small Forces Behind Tomorrow's Big Changes. First Edition. New York: Twelve.

Record 910,000 UK workers on zero-hours contracts. https://www.theguardian.com/business/2017/mar/03/zero-hours-contracts-uk-record-high.

Accessed: 22 January 2018.

Researchgate. www.researchgate.com 
Russell, J. (2013). 7 'digital nomads' explain how they live, work and travel anywhere in the world. https://thenextweb.com/insider/2013/12/15/7-digital-nomads-explain-how-they-live-workand-travel-anywhere-in-the-world/9/ Accessed on: 3 November 2017.

Saad, L. (2016). The "40-Hour" Workweek is Actually Longer - by Seven Hours. http://news.gallup.com/poll/175286/hour-workweek-actually-longer-seven-hours.aspx Accessed on: 20 October 2017.

Silverman, R. S. (2015). This Summer, How About a Workcation? http://www.wsj.com/articles/this-summer-how-about-taking-a-workcation-1435072989 Accessed on: 3 November 2016.

Süss, S., Sayah, S. (2013): Balance between work and life: A qualitative study of German contract workers. European Management Journal, 31(3), 250-262.

Trading Economics: www.tradingeconomics.com

US officially worst country in the world for paid annual leave. https://www.globalbankingandfinance.com/us-officially-worst-country-in-the-world-forpaid-annual-leave/ Accessed on: 6 December 2017.

Visit Britain. www.visitbritain.org

Wee Chan, Pervaiz, K. A. (2015): Exploring the effects of workplace support on work-life experience: a study of Malaysia. Human Resource Development International. http://www.tandfonline.com/doi/full/10.1080/13678868.2015.1019816?scroll=top\&needAc cess=true Accessed on: 4 December 2017. 